\title{
PROSES PENGURUSAN MUATAN ANGKUT LANJUT DAN DIANGKUT TERUS KHUSUS WILAYAH FREE TRADE ZONE (FTZ) PADA PT. SNEPNAC SHIPPING BATAM
}

\author{
${ }^{1}$ Khairuman, ${ }^{2}$ Taruna, ${ }^{3}$ Racmad Ozy Hutauruk \\ ${ }^{1,3} \mathrm{KPNK}^{, 2}$ TEKNIKA, Politeknik Adiguna Maritim Medan \\ email: ginting taruna76@gmail.com
}

\begin{abstract}
Abstrak. PT. Snepac Shipping Batam mempunyai peranan yang sangat penting dalam Proses pengurusan kegiatan kapal yang membawa muatan yang angkut lanjut dan diangkut terus ke kantor Bea Cukai. Peranan PT. Snepac Shipping Batam di mulai dalam memproses kegiatan angkut lanjut dan angkut terus dari sebelum kedatangan kapal sampai kapal akan berangkat ke pelabuhan selanjutnya, biasanya agen menerima manifest report, sertifikat registry atau surat laut, Bill of Loading, packing list dan dokumen lainya dari Kapten kapal, Ship Owner atau pencharter, Sebelum kedatangan kapal agen harus melakukan pemberitahuan Rencana Kedatangan Sarana Pengangkut (RKSP) ke kantor Bea dan Cukai paling lambat 24 jam sebelum kedatangan Sarana Pengangkut / kapal, selanjutnya akan keluar surat dengan nomor pendaftaran berupa BC 1.0 dari Bea Cukai. Setelah kapal tiba di pelabuhan maka selanjutnya harus mensubmit inward manifest dari sistem modul manifes Batam dan keluar surat dengan nomor pendaftaran berupa BC 1.1 in dan selanjutnya membuat permohonan online pada sistem Ionbeta Bea Cukai Batam dan melampirkan surat permohonan, surat pernyataan, surat kuasa dan dokumen Bill of Loading serta memasukan nomor pendaftaran berupa BC 1.1 in setelah surat persetujuan pengeluaran barang yang akan di angkut lanjut keluar maka selanjutnya melaporkan pemberitahuan inward manifest in ke kantor pelayanan penyidikan dan penindakan Bea Cukai dan turun bersama petugas ke kapal / dermaga untuk melakukan penyegelan terhadap muatan yang akan diangkut lanjut dan sebelum keberangkatan kapal harus mensubmit outward manifest terlebihdahulu maka akan keluar nomor pendaftaran berupa BC 1.1 out setelah itu ke kantor pelayanan penyidikan dan penindakan Bea Cukai untuk melaporkan outward manifest dan turun bersama petugas Bea Cukai ke dermaga untuk melakukan pembukaan segel terhadap barang yang akan diangkut lanjut, dalam melakukan pengurusan dokumen kapal di kantor Bea Cukai terdapat beberapa instansi - instansi terkait seperti Kantor Pelabuhan (KANPEL), Syahbandar, Karantina dan Imigrasi, PT. Snepac Shipping Batam selalu menjaga hubungan yang baik tersebut dapat menjaga proses pelancaran pengurusan dokumen kapal angkut lanjut dan angkut terus tersebut. Untuk pengambilan data Penulis menggunakan 2 (dua) jenis penelitian, yaitu metode penngumpulan data lapangan (field research) dan metode pengumpulan data pustaka (Library research).
\end{abstract}

Kata Kunci: Muatan,Free Trade Zone (FTZ),PT.Snepnac Batam

\begin{abstract}
PT. Snepac Shipping Batam has a very important role in the process of managing ship activities that carry cargo that is carried forward and transported directly to the Customs office. The role of PT. Snepac Shipping Batam begins in processing advanced transportation activities and transports continuously from before the arrival of the ship
\end{abstract}


until the ship will leave for the next port, usually the agent receives a manifest report, registry certificate or sea letter, Bill of Loading, packing list and other documents from the captain of the ship, Ship Owner or charterer, Prior to the arrival of the ship, the agent must notify the Plan of Arrival of Transport Facilities (RKSP) to the Customs and Excise office no later than 24 hours before the arrival of the means of transportation / ship, then a letter will be issued with a registration number in the form of BC 1.0 from Customs. After the ship arrives at the port, it must then submit an inward manifest from the Batam manifest module system and issue a letter with a registration number in the form of BC 1.1 in and then make an online application on the Batam Customs Ionbeta system and attach an application letter, statement letter, power of attorney and Bill document of Loading and enter the registration number in the form of BC 1.1 in after the approval letter for releasing the goods to be transported further out, then report the notification of the inward manifest in to the Customs and Excise investigation and enforcement service office and go down with the officers to the ship / dock to seal the cargo. will be transported further and before departure the ship must submit the outward manifest first then a registration number will be issued in the form of BC 1.1 out after that to the Customs and Excise investigation and enforcement service office to report the outward manifest and descend with Customs officers to the dock to check the opening of the seal for goods to be transported further, in managing ship documents at the Customs office there are several related agencies such as the Port Office (KANPEL), Syahbandar, Quarantine and Immigration, PT. Snepac Shipping Batam always maintains a good relationship, it can maintain the process of smoothing the document management for the onward and onward transport ship. For data collection the author uses 2 (two) types of research, namely the method of collecting field data (field research) and the method of collecting library data (Library research).

Keywords: : Load, Free Trade Zone (FTZ), PT. Snepnac Batam

\section{PENDAHULUAN}

Indonesia sebagai negara Kepulauan (Archipelagic States ) telah di tetapkan oleh United Nations Convention on the Law Of the Sea (UNCLOS) III, tahun 1982, diratifikasi pada tahun 1985 dan telah diikuti oleh Hukum Internasional pada tahun 1994. Dari pertumbuhan ekonomi suatu negara dapat dilihat satu diantaranya di bidang perdagangan, baik perdagangan Nasional maupun Internasional. Negara Indonesia salah satu negara dengan melakukan sistem perdagangan ekspor maupun impor.

Hal ini berpengaruh terhadap pertumbuhan ekonomi Nasional yang harus diikuti oleh perkembangan sarana dan prasarana transportasi khususnya melalui angkutan laut.

Angkutan laut yang mempunyai karakteristik pengangkut secara Nasional dan menjangkau seluruh wilayah melalui perairan perlu dikembangkan potensi dan ditingkatkan peranannya sebagai penghubung antar wilayah, baik Nasional maupun Internasional.

Kegiatan utama perusahaan pelayaran adalah mengoperasikan kapal milik atau kapal yang di carter agar hasilnya sesuai yang diinginkan oleh perusahaan untuk memperoleh keuntungan. Untuk menunjang keberhasilan pengoperasian kapal, operator yang handal, dinamis, dan professional dalam bidangnya masing-masing.

Perusahaan pelayaran sebagai perusahaan jasa yang melayani pengguna jasa pelabuhan, dimana suatu pelayanan yang diberikan oleh pemberi jasa dengan efektif dan efisien dengan teknik atau metode yang benar, serta proses pelayanan muatan dari pelabuhan asal atau pemuatan hingga pelabuhan tujuan atau pembongkaran dapat dilaksanakan dengan cepat, lancar dan biaya yang relatif murah untuk menunjang terselenggaranya angkutan laut untuk meningkatkan pelayanan muatan kapal maka PT. Snepac shipping Batam harus meningkatkan 
ruang lingkup dari mutu pelayanan serta produktifitas kerjanya.

\section{METODE PENELITIAN}

Dalam penulisan ini menggunakan 2 (dua) jenis metode penelitian dalam pengumpulan data yaitu :

1.Penelitian Lapangan (Field Research)

Penelitian lapangan yang digunakan penulis adalah :

a.Interview (wawancara) kepada pembimbing lapangan serta para karyawan perusahaan PT. Snepac Shipping Batam serta petugas yang berwenang memberi data yang diperlukan untuk melengkapi data yang diperlukan untuk penulisan makalah.

b.Observasi (pengamatan) yang langsung penulis lakukan terhadap subjek yang dibahas, mengamati dan meneliti tatacara sebagai bukti pengamatan tersebut dengan terjun langsung ke lapangan baik kepelabuhan tempat kapal sandar maupun ke instansi - instansi yang bersangkutan.

2).Penelitian Pustaka (Library Research)

Pengumpulan data pustaka adalah studi yang dipergunakan oleh penulis melalui penelitian dengan membaca buku - buku yang ada di perpustakaan PT. Snepac Shipping Batam dan membaca Undang-Undang yang sedang berlaku pada instansi terkait .

\section{HASIL DAN PEMBAHASAN}

\section{A. Sejarah Singkat Perusahaan}

Perusahaan pelayaran PT. Snepac Shipping Batam didirikan sesuai dengan akte pada tanggal 24 Juli 2003 yang berkantor pusat dahulu bernama PT. Nusantara Perkasa, dan tercatat sebagai pendiri bapak Zulkifli Ali yang bertindak sebagai pemilik perusahaan. Pada saat itu PT. Snepac Shipping Batam hanya mengoperasikan kapal KM. Tenaga Baru II dan kapal KM. Tenaga Baru 8. Perusahaan ini terus berkembang sehingga pada tahunn 2005 mengoperasikan 6 kapal rutin dan kapal milik PT. Nusantara Perkasa di ubah dengan status hukum yakni perusahaan PT. Snepac Shipping Batam dengan akta notaris NO. 29 tanggal 24 Juli 2003.

Perkembangan demi perkembangan yang di alami oleh PT. Snepac Shipping Batam dan jangkuan transportasi cukup luas, yaitu melayani pengangkut dalam negeri maupun luar negeri. Dalam hal ini diperlukan perbentukan perwakilan PT. Snepac
Shipping Dumai, Selat Panjang, Jakarta, tarempa, Sorong, Balikpapan,Surabaya, Probolinggo, Tanjung Uban dan Lamongan dan berstatus sebagai kantor Cabang.

Adapun pertimbangan mendirikan perusahaan cabang ini ialah di karenakan adanya perkembangan yang di alami oleh PT. Snepac Shipping Batam pada waktu mengunjungi pelabuhan di luar kota Batam dan tingginya tingkat permintaan kebutuhan utuk melayani kapal - kapal serta muatan yang di luar Batam.

\section{B. Prosedur Pembongkaran dan Pemuatan Barang Impor atau Barang Ekspor dari dan Ke sarana Pengangkut Untuk Diangkut lanjut}

1).Pembongkaran dan pemuatan barang impor atau barang ekspor dari dan ke sarana pengangkut untuk diangkut lanjut wajib dilakukan di kawasan pabean.

2).Pembongkaran barang impor di luar kawasan pabean untuk diangkut lanjut, dilaksanakan sesuai dengan ketentuan peraturan perundang - undangan mengenai pembongkaran barang impor.

3).Pembongkaran barang ekspor di luar kawasan pabean untuk diangkut lanjut dapat dilkakukan jika barang ekspor diangkut lanjut dari dalam daerah pabean menggunakan sarana pengangkut dengan trayek antara antar wilayah dalam daerah pabean.

4).Pemuatan barang impor atau barang ekspor ke sarana pengangkut untuk diangkut lanjut, dapat dilakukan di luar kawasan pabean jika:

a). Barang impor atau barang ekspor diangkut lanjut kedalam daerah pabean menggunakan sarana pengangkut dengan trayek antar wilayah dalam daerah pabean; atau

b).Barang impor atau barang ekspor yang diangkut lanjut dilakukan pembongkaran dan pemuatan dari dan ke sarana pengangkut tanpa dilakukan penimbunan (Ship to Ship).

5).Pembongkaran barang ekspor di luar kawasan pabean untuk diangkut lanjut dan pemuatan barang impor atau barang ekspor ke sarana pengangkut untuk diangkut lanjut dilakukan setelah mendapat izin dari kepala kantor pabean yang mengawasi tempat pembongkaran

6).erhadap pembongkaran dan/atau pemuatan barang impor atau barang ekspor dari atau ke sarana pengangkut untuk diangkut lanjut, dilakukan pengawasan secara selektif berdasarkan manajemen risiko. 


\section{C.Cara penerbitan Surat Persetujuan Pengeluaran Barang (SPPB) Untuk Diangkut Lanjut dan Diangkut Terus}

1).Surat persetujuan pengeluaran barang (SPPB) untuk diangkut lanjut adalah surat yang di buat secara online lewat sistem Bea Cukai Ionbeta dengan melampirkan yaitu :
a. Surat permohonan dari perusahaan
b.Surat pernyataan dari perusahaan
c.Surat kuasa dari perusahaan
d.Packing list
e.Manifest in
f.BC 1.1 Inward
g.Bill of lading
h.Invoice
i. Berita acara penyegelan

2).Surat persetujuan pengeluaran barang (SPPB) untuk diangkut terus adalah surat yang dibuat secara online lewat sistem Bea Cukai Ionbeta dengan melampirkan yaitu :

a.Surat permohonan dari perusahaan

b.Surat pernyataan dari perusahaan

c.Packing list

d.Manifest in

e.BC 1.1 Inward

f. Bill of lading

g.Invoice

\section{D.Proses pengisian data Manifest di sistem online Modul Bea Cukai Batam}

1).Satu hari atau 24 jam sebelum kedatangan sarana pengangkut, agen pelayaran wajib memberitahu rencana kedatangan sarana pengangkut ( RKSP ) ke sistem online modul Bea Cukai batam, setelah disubmit atau melaporkan kedatangan kapal maka akan keluar nomor pendaftaran berupa BC 1.0.

Agen pelayaran melakukan pengisisan data modul pengangkut yang berisikan data - data untuk melaporkan rencana kedatangan sarana pengangkut (RKSP) adalah sebagai berikut :

a.Nama kapal

b. Bendera / kebangsaan kapal

c.Nama Nakhoda kapal

d.Nomor pelayaran ( voyave number )

e.Nama perusahaan agen kapal

f. Pelabuhan asal / pelabuhan muat

g.Pelabuhan tujuan / pelabuhan bongkar

h.Pelabuhan transit

i. Tanggal dan jam kedatangan kapal

j. Jumlah bill of lading
k.Nomor dan tanggal bill of lading

1. Nama dan alamat pengirim (shipper / suplier)

m.Nomor dan merek kemasan / peti kemas

n.Jumlah dan jenis kemasan / peti kemas

o.Ukuran dan tipe kemasan / petikemas

p.Uraian barang atau muatan

q.Berat kotor (bruto) Muatan

r. Ukuran atau volume muatan

2).Setelah kapal sudah sampai di pelabuhan atau 24 jam setelah kedatangan kapal maka agen akan mensubmit Inward manifest dan akan keluar nomor pendaftaran berupa BC.1.1 in.

Agen pelayaran melakukan pengisisan data modul pengangkut yang berisikan data - data untuk melaporkan kedatangan kapal adalah sebagai berikut:

a.Nama kapal

b.Bendera / kebangsaan kapal

c.Nama Nakhoda kapal

d.Nomor pelayaran ( voyave number )

e.Nama perusahaan agen kapal

f. Pelabuhan asal / pelabuhan muat

g.Pelabuhan transit

h.Tanggal dan jam kedatangan kapal

i. Jumlah bill of lading

j. Nomor dan tanggal bill of lading

k.Nama dan alamat pengirim (shipper / suplier)

1. Nomor dan merek kemasan / peti kemas

m.Jumlah dan jenis kemasan / peti kemas

n.Ukuran dan tipe kemasan / petikemas

o.Uraian barang atau muatan

p.Berat kotor (bruto) Muatan

q. Ukuran atau volume muatan

Untuk pada saat pemilihan kelompok pos dalam sistem online Bea Cukai Batam kawasan bebas untuk muatan angkut lanjut dan angkut terus yaitu :

a).Kelompok pos 21 yaitu "barang asal luar daerah atau petikemas kosong yang kewajiban pabeanya tidak di selesaikan di kantor pabean di kawasan bebas lainya".

b).Kelompok pos 23"barang asal kawasan bebas lain atau petikemas kosong yang kewajiban pabeanya tidak di selesaikan di kantor pabean di kawasan bebas lainya".

c).Kelompok pos $25^{\prime \prime}$ barang asal tempat lain dalam daerah pabean atau petikemas kosong yang kewajiban pabeanya tidak di selesaikan di kawasan bebas “.

3).Pada saat kapal akan berangkat atau 24 jam sebelum keberangkatan kapal maka agen pelayaran 
akan mensubmit outward manifest, maka akan keluar nomor pendaftaran berupa BC 1.1 out.

Agen pelayaran melakukan pengisisan data ke sistem online modul Bea Cukai yang berisikan data data untuk melaporkan keberangkatan kapal adalah sebagai berikut :

a.Nama kapal

b.Bendera / kebangsaan kapal

c.Nama Nakhoda kapal

d.Nomor pelayaran ( voyave number )

e.Nama perusahaan agen kapal

f. Pelabuhan tujuan / pelabuhan bongkar

g.Pelabuhan transit

h.Tanggal dan jam keberangkatan kapal

i. Jumlah bill of lading

j. Nomor dan tanggal bill of lading suplier)

k.Nama dan alamat pengirim (shipper /

1. Nama dan alamat penerima (consignee)

m.Nomor dan merek kemasan / peti kemas

n.Jumlah dan jenis kemasan / peti kemas

o.Ukuran dan tipe kemasan / petikemas

p.Uraian barang atau muatan

q.Berat kotor (bruto) Muatan

r. Ukuran atau volume muatan

Untuk pada saat pemilihan kelompok pos dalam sistem online modul Bea Cukai Batam kawasan bebas untuk muatan angkut lanjut dan angkut terus yaitu :

a).Kelompok pos 30 yaitu "barang atau petikemas kosong tujuan luar daerah pabean".

b).Kelompok pos 31 yaitu "barang atau petikemas kosong tujuan kawasan bebas lain".

c).Kelompok pos 32 yaitu "barang atau petikemas kosong tujuan tempat lain dalam daerah pabean".

Pemilihan kelompok pos unntuk keberangkatan yang membawa muatan angkut lanjut dan angkut terus berdasarkan dari tujuan keberangkatan kapal, jika kapal tujuan luar negeri maka untuk pemilihan kelompok pos nya adalah kelompok pos 30, jika kapal tujuan ke kawasan bebas lainya dalam negeri untuk pemilihan kelompok pos nya adalah 31 , jika kapal tujuan tempat lain dalam daerah pabean adalah kelompok pos 32. Setelah selesai melakukan pengisian data pada sistem online modul Bea Cukai, maka selanjutnya data akan di cetak untuk lampiran dokumen ke kantor pelayanan penyidikan dan penindakan Bea Cukai Batam untuk melakukan clearance in dan out atau melaporkan kedatangan dan keberangkatan kapal.
E.Lampiran Clearance in dan out ke Kantor Pelayanan Penyidikan dan Penindakan Bea Cukai Batam

1).Lampiran - lampiran dokumen untuk melapor atau clearance ke kantor pelayanan penyidikan dan penindakan Bea Cukai Batam untuk kedatangan kapal dengan muatan angkut lanjut yaitu:

a.Port clearance

b.Crew list

c.Inward manifest

d.Bill of lading

e.BC 1.1 inward

f. Store list

g.Manifest dari pelabuhan asal

h. Surat perintah Bea dan Cukai

i. Berita acara pemeriksanaan

j. Laporan hasil pemeriksaan

k.Berita acara penyegelan

1. Lembar cek list kelengkapan dokumen

2).Lampiran - lampiran dokumen untuk melapor atau clearance ke kantor pelayanan penyidikan dan penindakan Bea Cukai Batam untuk keberangkatan kapal dengan muatan angkut lanjut yaitu:

a.Port clearance

b.Crew list

c. Outward manifest

d.BC 1.1 out

e.Surat perintah Bea dan Cukai

f. Berita acara pemeriksanaan

g.Laporan hasil pemeriksaan

h.Berita acara pembukaan segel

i. Lembar cek list kelengkapan dokumen

j. Surat persetujuan pengeluaran barang untuk diangkut lanjut (SPPB)

k.Berita acara penyegelan

3).Lampiran - lampiran dokumen untuk melapor atau clearance ke kantor pelayanan penyidikan dan penindakan Bea Cukai untuk kedatangan kapal dengan muatan angkut terus yaitu :

a.Port clearance

b.Crew list

c.Inward manifest

d.Bill of lading

e.BC 1.1 inward

f. Store list

g.Manifest dari pelabuhan asal

h. Surat perintah Bea dan Cukai

i. Berita acara pemeriksanaan

j. Laporan hasil pemeriksaan

k.Lembar cek list kelengkapan dokumen 
4).Lampiran - lampiran dokumen untuk melapor atau clearance ke kantor pelayanan penyidikan dan penindakan Bea Cukai Batam untuk keberangkatan kapal dengan muatan angkut terus yaitu:
a.Port clearance
b.Crew list
c.Outward manifest
d.BC 1.1 out

e.Surat perintah Bea dan Cukai

f. Berita acara pemeriksanaan

g.Laporan hasil pemeriksaan

h.Lembar cek list kelengkapan dokumen

i. Surat persetujuan pengeluaran barang untuk di angkut terus (SPPB)

Setelah lampiran dokumen sudah lengkap maka semua dokumen dibawa ke kantor pelayanan pos penyidikan dan penindakan Bea Cukai dan turun bersama petugas ke kapal atau dermaga untuk melakukan penyegelan terhadap barang yang ingin diangkut lanjut dengan tujuan supaya tidak ada pemindahan barang atau pengeluaran barang sebelum kapal selanjutnya yang ingin membawa barang selanjutnya datang dan akan dilakukan pembukaan segel oleh petugas yang berwenang.

\section{F.Hambatan - Hambatan yang Dihadapi Dalam Memproses angkut lanjut dan diangkut terus}

1).Lamanya dapat approve dari petugas administrasi manifest Bea Cukai sehingga surat persetujuan pengeluaran barang (SPPB) terlambat di terbitkan.

2).Jika terjadi kesalahan dalam pembuatan inward manifest dan outward manifest sistem maka akan membutuhkan waktu yang sangat lama dalam memperbaikinya, sehingga bisa menimbulkan keterlambatan keberangkatan kapal.

\section{KESIMPULAN}

Proses pengurusan muatan angkut lanjut dan diangkut terus khusus wilayah free trade zone (FTZ) pada PT. Snepac Shipping Batam telah berlangsung dengan baik, Namun prosesnya adalah sebagai berikut :

1).Menyiapkan semua lampiran dokumen yang dibutuhkan yang diminta dari owner / pencharter oleh Trefic department.

2).Satu hari atau 24 sebelum kedatangan kapal mensubmit rencana kedatangan sarana pengangkut (RKSP).
3).Setelah kapal tiba atau 24 jam kedatangan kapal maka akan mensubmit inward manifest.

4).Setelah mensubmit inward manifest selanjutnya clearance in atau melaporkan kedatangan kapal yang membawa muatan angkut lanjut atau angkut terus.

5).Turun ke kapal atau pelabuhan bersama petugas penyidikan dan penindakan Bea Cukai untuk melakukan penyegelan dan pemeriksaan muatan.

6).Membuat surat permohonan online ionbeta Bea Cukai untuk penerbitan Surat Persetujuan Pengeluaran Barang (SPPB).

7).Sebelum keberangkatan kapal atau 24 jam sebelum kapal berangkat maka akan mensubmit outward manifest

8).Setelah mensubmit outward manifest selanjutnya Clearance out atau melaporkan keberangkatan kapal yang membawa muatan angkut lanjut dan diangkut terus.

9).Turun ke kapal bersama petugas penyidikan dan penindakan Bea Cukai untuk melakukan pembukaan segel dan pemeriksaan muatan angkut lanjut atau angkut terus.

\section{DAFTAR PUSTAKA}

Budi Santoso, Keagenan, Jakarta : Ghalia Indonesia, 2015

Fakhrurrozi, Penanganan Pengaturan dan Pengamanan Muatan Kapal, Semarang : AKPELNI 11111111112017

KBBI (Kamus Besar Bahasa Indonesia), 2016 Undang - Undang No. 17 Tahun 2008 tentang Pelayaran.

Peraturan Menteri Keuangan Republik Indonesia Nomor. 216/ PMK. 04/ 2019 Tentang Angkut Terus dan Angkut Lanjut Barang Impor dan Barang Ekspor.

https://beacukaiku.wordpress.com 